\title{
Information Spillover and Demand Shock Effect of the IPOs on the Stock Price of the Competitors: Evidence From the Korean Stock Market
}

\author{
Jae Hoon Min $^{1}$ \\ ${ }^{1}$ School of Business, Seowon University, Cheongju, South Korea \\ Correspondence: Jae Hoon Min, School of Business, Seowon University, 377-3 Mooshimseo-ro, Seowon-gu, \\ Cheongju 28674, South Korea. Tel: 82-43-299-8621.
}

Received: July 9, 2020

Accepted: August 12, 2020

Online Published: September 21, 2020

doi:10.5430/ijfr.v11n5p1

URL: https://doi.org/10.5430/ijfr.v11n5p1

\begin{abstract}
This paper examines the impact of IPOs on the stock prices of competing companies in the same industry in the Korean stock market. By observing the stock price responses of competitors at the time of IPO announcement and listing, this study attempts to separately examine the effect of IPO's information transfer and its impact on the stock demand of competitors. Before and after the IPO announcement, the stock prices of competitors did not change significantly. On the other hand, during the period surrounding the IPO stock listing, the stock price of competitors showed a significantly negative decline. This suggests that as the IPO stock related information was revealed through the public offering process, it negatively affected the stock price of competing companies. Also, the listing of IPO stocks seems to have adversely affected the stock demand for competing companies. In particular, among the effects of information transfer, the competitive effect is overwhelming, and the factors that influence relative competitiveness in the industry between competitors and an IPO company, such as operating profitability and R\&D investment, are found to have a substantial influence on the share price of competitors.
\end{abstract}

Keywords: initial public offering, information spillover, the demand shock

\section{Introduction}

This paper examines the economic effect of the IPO on the stock prices of competing companies in the Korean stock market. IPO could be regarded as an event that affects the industry as a whole, not just an individual company if it affects the competitor's stock price as well as the stock price of IPO firm on average. Until now, little research has been done on the effect of IPOs on the prices of existing listed stocks in the same industry in the Korean stock market.

The economic effects of IPOs on competitors' stock prices can be divided into two categories. The first is related to the information spillover effect of the IPO on the stock prices of competitors in the industry. The information spillover effect is further divided into the contagion effect and the competitive effect. With respect to the contagion effect that predicts a positive correlation in stock returns between IPO firms and the competitors, IPO may transfer information about the prospects for growth in the industry, eliciting a positive stock price reaction of competing firms. Concerning the negative competitive effect, IPO could weaken the relative competitiveness of the competitors in their industry and cause the competitor's share price to change unfavorably compared to the newly listed company after the IPO. Second, regardless of the information transfer effect, IPOs supply the new shares to the stock market from the perspective of investors, which can alter the demand-supply equilibrium of stocks of the existing listed companies and cause their stock prices to fall.

So far, many studies have analyzed the spillover effect of information related to various topics. Foster (1981) examined the impact of the earnings releases on the stock prices of other competing companies in the industry. Lang and Stulz (1992) investigated the effect of a company's bankruptcy on the stock prices of competing companies in the industry. Laux, Starks, and Yoon (1998) analyzed the impact of large dividend adjustments on the stock prices of rival companies, and Chen, Ho and, Shih (2007) reported on the effect of corporate capital investment on the stock price of the competitors. Most of their studies concluded that whether the contagion effect outweighs the competitive effect or vice versa depends on the industry and firm-specific characteristics.

Regarding the effect of one company's financing policy on other companies in the industry that are related to the 
subject of this study, Szewczyk (1992) reported that the public offering of securities, including stocks, convertible bonds, and corporate bonds, send a negative signal to the investors about the industry prospects, depressing the stock prices of not only securities issuers but also competitors. In particular, it was considered that the act of reducing the debt ratio, such as the issuance of new shares, suggests a lack of confidence in the management of future profitability. Bradley and Yuan (2013) reported asymmetric stock price responses of the competing firms to the announcement of primary versus secondary seasoned equity offerings. The share prices of competitors responded positively to the new equity issuance because primary equity offerings are considered to raise profitable investment opportunities, reflecting the favorable prospect of the industry. On the other hand, the sale of insiders led to the decline in share prices of the rival firms, signaling that the share price is overvalued across the industry.

Regarding prior studies on the impact of IPO announcements on competitors' stock prices, Akhigbe, Borde, and Whyte (2003) reported that IPO announcements did not significantly affect competitors' stock prices. They insisted that IPOs are conducted when investors are optimistic about the industry prospects, so the positive information effect provided by IPOs can be spilled over to the competitors' share prices. However, if IPO proceeds are used to expand facilities or strengthen competitiveness, IPO will re-evaluate the competitive position of the IPO firm within the industry. That is, on average, the positive contagion effect and the negative competitive effect on the competitors' stock prices seemed canceled out. On the other hand, Slovin, Sushka, and Ferraro (1995) stated that when a management conduct equity carve-outs (IPOs of subsidiary equity) through the sale of an affiliate's stake, the share price of a competitor in the industry is also negatively affected. The reason for this is because the IPO is undertaken when outside investors evaluate the value of equity more than managers think and so, equity carve-outs signal that the stock price in the industry has been overvalued. In this regard, many prior studies have already supported the timing hypothesis of stock issuance when managers believe the share price is overvalued (Myers and Majluf, 1984; Ritter 1991; Baker and Wurgler, 2000). Hsu, Reed, and Rocholl (2010) also note that the entry of new companies into the stock market is an adverse event for existing competitors, which not only negatively affects the stock returns of existing companies surrounding the IPO announcement, but also negatively affects the future operating performance of existing companies. According to them, there are three major competitive advantages of IPO: an enhanced investment capacity and improved financial stability due to increased liquidity, and increased investor pool due to the certification effect of the underwriting institution, and the improvement of competitiveness due to the accumulation of knowledge capital through increased R\&D investment. Chod and Lyandres (2011) argued that IPO companies' aggressive market strategies, such as an expansion of production capacity, in the presence of competition and demand uncertainty in the product market, hurt the market share and share price of competitors. In a similar sense, Chemmanur and He (2011) also cited an improved relationship with consumers and suppliers, recruiting competent employees and strengthening their compensation using stocks and stock options, and enhancing the acquiring ability of other companies as IPO benefits. They insisted that IPO erode the market share of these other competitors, especially unlisted companies. Among the studies on stock markets other than the United States, McGilvery, Faff, and Pathan (2012) found that rival firms in the industry experienced negative stock price reactions to the completion of IPOs in the Australian market. They observed that if IPO companies have a solid corporate governance structure and use IPO proceeds to strengthen competitiveness in the industry, such as for investment or debt reduction, IPOs have a more negative impact on the stock prices of existing competitors. In the Chinese market, $\mathrm{Li}$, Shen, Wang, and Zhang (2019) also documented a strong competitive effect in that positive (negative) analyst recommendations on rival firms tend to decrease (increase) the first-day return of IPO stocks, especially in the highly competitive and correlated industries.

Regardless of the information effect of the IPO event itself, it is argued that the impact on the stock investment demand of competitors adversely affects the share price. Given the difficulty of perfect arbitrage assumed in financial theory in the real world, the supply of new stocks due to the IPO means the emergence of competitive substitutes for investors of existing publicly traded stocks in the industry. The downward shift in the demand curve of the existing listed stock should cause the share price to fall accordingly. According to Braun and Larrain (2009) on 22 emerging stock markets, an increase in the supply of one security shifts the demand curve of another security downwards, so issuing new shares has a permanent effect on the prices of existing stocks. In particular, they argued that the higher the correlation with IPO stock, the better the IPO stock would be a good substitute for competing stocks, and the greater the impact of demand when new securities were issued. Their study observed that the value of a portfolio constructed with competing stocks highly correlated with an IPO company fell for a month after the IPO. In particular, the larger the IPO size, the greater the impact of demand, and the higher a competitor's stock price decline. They denied the information transfer hypothesis and argued that the change in stock prices caused by the IPO was due to changes in expected returns, not new information related to future cash flows. In the Chinese market, Li, Sun, 
and Tian (2018) also reported a stock price decline of the competitors to the IPO approval announcements as well as the listing of IPO stocks. Ruling out the information transfer effect, they insisted that IPO news could influence prices of other stocks by shaping the expectation of a change in the supply-demand equilibrium without actual trading of IPO shares. In a similar vein, Slovin, Sushka, and Bendeck (1991) analyzed the impact on the share price of competing companies by announcing going private for the public company, which is an act contrary to the IPO. According to their study, the share price of competing companies increased positively with the announcement, and in particular, the larger the market capitalization of the companies to be delisted compared to the competing companies, the more the competing companies' stock price rose. This could indirectly be seen as a result of supporting the IPO's demand shock hypothesis.

Up to now, previous studies have presented mixed conclusions about the information spillover effect of IPOs on the stock price of competitors and the effect of the supply of new stocks on demand for rival stocks. This study aims to examine which effects have more influence on the stock prices of competitors by analyzing the information spillover effect and demand shock effects of IPOs in the Korean market. In addition, this study attempts to investigate which of the contagion and competitive effects is more pronounced if the information transfer effect is observed.

\section{Hypotheses}

The purpose of this study is to investigate the changes in stock prices of competing companies before and after the IPO announcement date (the date of the initial filing of the registration statement) and the date of listing on the stock market. Assuming that the effect of information provided by the IPO in an efficient stock market is preemptively reflected in the share price at the time of the public announcement, the change in share price at the time of listing should result from a decrease in demand to existing stocks due to the emergence of competitive substitutes, and it can be said that it reflects only the demand shock on the rival firms' stocks. To separate these two effects, this study examines the information spillover effect and the demand shock effect separately by observing the share price changes of competitors at the time of IPO disclosure and listing.

Most previous studies in other stock markets have reported that IPOs have a negative impact on the stock prices of existing listed companies in the industry. By observing whether the share price change of the existing competitors in the Korean stock market around the IPO public announcement date is positive or negative, this study will investigate which of the information transfer effect of the IPO, the contagion effect, or the competitive effect, is overwhelming.

Hypothesis 1. At the time of the IPO announcement (the date of filing a registration statement), the stock prices of existing listed companies in the industry decline significantly.

Through hypothesis 2 below, this study also tries to examine the significance of the demand shock impact of IPOs on the stock prices of competing companies after a new IPO stock starts trading in the market.

Hypothesis 2. At the time of listing of IPO stock, the stock prices of existing listed companies in the industry decline significantly.

Next, this study intends to investigate the factors that have a close influence on the share price changes of competing companies at the time of IPO announcement or listing. As mentioned earlier, the impact of IPO on the stock price of competitors is largely divided into the information spillover effect and demand shock effect. By examining the factors affecting the supply and demand of IPO stocks and those factors that are closely related to the industrial competitiveness of IPO companies and existing competitors, this study attempts to investigate how these factors have a significant impact on the stock prices of existing listed companies. Braun et al. (2009) denied the effect of IPO's information transfer and argued that the share price change of competitors was due to the demand shock caused by IPO, while Hsu et al. (2010) denied the effect of supplying new shares from IPO and argued that the difference in stock performance of competing companies after the IPO was due to the difference in their competitiveness relative to IPO company in the industry. Through hypothesis 3 , this study tries to verify the effect of factors affecting the investment demand of IPO stocks on the stock price of existing companies. For example, the greater the attractiveness of IPO stocks as a substitute for existing stocks, the more likely it will have an adverse effect on the stock prices of competitors.

Hypothesis 3. The increase in the investment demand for IPO stocks has a negative effect on the stock prices of existing listed companies.

In addition, through hypothesis 4, this study attempts to verify the impact of the factors related to the supply of IPO stocks on the stock prices of existing companies following the listing of IPO stocks. The larger the size of new public offerings and the higher the ratio of stocks that can be traded immediately to total listed shares, the more likely it will have an adverse effect on the share price of competitors. 
Hypothesis 4. The larger the supply of IPO stocks, the more it has an adverse effect on the stock prices of existing listed companies.

Previous studies such as Chan, Martin, and Kensinger (1990), and Hsu et al. (2010) have emphasized the importance of investing in $R \& D$ to improve the long-term growth and competitiveness of the company. According to Chan et al. (1990), investors recognized R\&D expenditure as a strategic investment in the long term, and even if a company has a low profit in the short term, the share price responds favorably to R\&D investment announcement. Hsu et al. (2010) also argued that investments in knowledge capital, such as investments in R\&D, enhance the competitiveness of companies. Therefore, this study suggests that if a new IPO company entering the stock market focuses on strategic investments such as $R \& D$ investment, it is expected to weaken the competitiveness of existing companies and adversely affect the stock prices of competitors.

Hypothesis 5. The listing of a competitive IPO company with high R\&D expenditures adversely affects the stock price of existing listed companies.

\section{Data and Research Method}

\subsection{The Structure of the Korean Stock Market and the IPO Process in Korea}

There are three stock markets on the Korea Exchange (KRX): KOSPI, KOSDAQ, and KONEX. Among them, large-cap, blue-chip stocks are listed on the KOSPI market, and small and medium-sized stocks and venture companies' stocks are traded on the KOSDAQ market. The KONEX market was opened in 2013 to support small-sized start-ups, but these companies were excluded from this study because the KONEX is the market for prospective companies for listing on the KOSPI or KOSDAQ market. As of the end of 2018, the KRX is the world's 13th largest stock exchange in terms of market capitalization, and 788 companies were listed on the KOSPI market with total market capitalization amounting to Korean Won 1,343 trillion. On the KOSDAQ market, 1,323 companies were listed with total market capitalization amounting to Korean Won 228 trillion.

The IPO in the Korean stock market is done through a competitive auction process similar to that of developed countries. Companies that want to go public submit their registration statements to the financial supervisory authorities through the investment bank. In addition, efforts should be made to meet the listing standards required by the Korea Exchange in advance. The lead underwriter suggests a price range of tentative offering price through their corporate analysis in the prospectus. Subsequently, the final offering price is determined through the book-building procedure for institutional investors. Among institutional investors participating in book-building, only institutional investors who submit a limit bid that has a price above the final offer price or a strike bid that presents only the desired quantity without a specified price will be allocated public offerings. Individual investors and employee stock ownership plan (ESOP) will subscribe to the final offer price. Roughly, the public offerings are allotted to institutional investors, individual investors, and ESOP at a 7:2:1 ratio.

\subsection{Data}

This study was conducted on IPOs that occurred in the Korea Exchange (KRX) from July 2007 to the end of 2017. A total of 531 IPO companies are selected, excluding financial companies, special purpose acquisition companies (SPAC), and foreign companies. In this study, the rival firms of IPO companies were selected through the following methods. In the "underwriter's opinion" section of the prospectus, the lead underwriter provides the data for the offer price band to institutional investors participating in the book-building procedure. Among the data provided by the lead manager is a list of peer companies already listed on the stock market that are in the same industries, with a similar sales composition and company size, and financial structure. Their price multiples (PER, PBR, EV/EBITDA, etc.) and financial ratios serve as a reference for the price band. Through this process, 2,443 competing firms are finally matched with IPO companies.

To obtain the list of IPO companies, the KRX's corporate disclosure site (http://kind.krX.co.kr) was used. For detailed information related to the registration statement, the Korea Financial Supervisory Service's electronic disclosure system (http://dart.fss.or.kr) was used. The return information of listed companies used in this study was obtained from FnGuide's DataGuide database, and financial statements information was obtained from the TS-2000 database of the Korean Listed Companies Council. 
Table 1. The variables related to the IPO characteristics and firm competitiveness in the industry

\begin{tabular}{ll}
\hline Variable & Description \\
\hline PINDURET & Past industry returns for a year before IPO \\
YRDIS & The median value of offer price discount of IPOs that occurred a year ago \\
PROCEED & IPO proceeds \\
FLOAT & $\begin{array}{l}\text { The ratio of the number of shares that can be traded immediately after the IPO to the number } \\
\text { of total listed shares, excluding the number of stocks locked-up of large shareholders and } \\
\text { ESOP. }\end{array}$ \\
& $\begin{array}{l}\text { Offer price discount calculated as the first trading day's closing price divided by offer price } \\
\text { minus 1 }\end{array}$ \\
DISCOUNT & Individual investors' subscription rate of IPO shares \\
INDCOMP & Competition rate of institutional investors participating in the book-building for IPO stocks \\
INSTCOMP & The proportion of strike bids of institutional investors participating in the book-building for \\
STKBID & IPO stocks \\
IPO_AGE & The period from the foundation of the IPO firm to the IPO announcement date (months) \\
IPO_ASSET & The total asset of the IPO company \\
IPO_EBITDAR & EBITDA to sales ratio of the IPO company \\
IPO_DEBTR & The debt ratio of the IPO company \\
IPO_R\&D & R\&D expenditures to sales ratio of the IPO company \\
HHI & Herfindahl-Hirschman Index \\
GAP_AGE & Competing firms' age minus the IPO firm's age \\
GAP_ASSET & Competing firms' total asset minus the IPO firm's total asset \\
GAP_EBITDAR & Competing firms' EBITDAR minus the IPO firm's EBITDAR \\
GAP_DEBTR & Competing firms' debt ratio minus the IPO firm's debt ratio \\
GAP_R\&D & Competing firms' R\&D ratio minus the IPO firm's R\&D ratio \\
\hline
\end{tabular}

Table 1 summarizes the variables used in this paper in three parts to analyze the effect of IPO on the stock price of existing listed companies in the industry. First, as the variables related to the stock market condition and the industrial environment, the past industry return (PINDURET) and the median value of the offer price discount (YRDIS) one year before IPO are used. Previous studies have reported that IPO investment demand is influenced by past industry returns, and the IPO stocks' first-day return (i.e., the offer price discount) is positively affected by the past offer price discount (Lowry and Schwert, 2002; Derrien, 2005).

The second part of the variables is the factors affecting the demand of existing publicly traded stocks, which are related to the supply shock and investment attractiveness of the IPO stocks. These variables are mainly used to test hypotheses related to the demand shock effect given by IPOs, as argued in Braun et al. (2009). The larger the IPO's proceeds (PROCEED), the greater the proportion of stocks that can be traded immediately after the listing to all listed shares (FLOAT), the greater the impact on the existing stocks. The initial return of the IPO stock (DISCOUNT), the individual investor's subscription rate (INDCOMP), and the institutional investor's demand for IPO stocks (INSTCOMP) are indicators reflecting the size of the investment demand for IPO stocks and the hotness of IPO. The higher these ratios, the greater the attractiveness of the IPO stock as a substitute to existing listed stocks. Besides, this study considers the proportion of strike bids (STKBID) of institutional investors participating in the book-building process as a key variable representing a strong demand for IPO stocks because institutional investors who submit a strike bid express their willingness to accept whatever the final offer price would be in their bidding.

The third set of variables reflects the relative competitiveness in the industry between IPO companies and existing listed companies. These variables are used to test the hypothesis that IPO affects changes in the relative competitiveness of companies in the industry, as proposed by Hsu et al. (2010). These variables include the IPO firm's age (IPO_AGE), total assets (IPO_ASSET), profitability (IPO_EBITDAR), financial soundness (IPO_DEBTR), and research \& development intensity (IPO_R\&D). The age of the IPO firm (IPO_AGE) reflects the amount of available information about the company and the maturity of the company, which is necessary for investment decisions. Total assets (IPO_ASSET) represent the size of the company. In particular, R\&D expenditures 
refer to investments in knowledge capital that will influence a company's future competitiveness and long-term performance. (Chan et al. 1990; Hsu et al.; 2010). Also, variables such as differences in the number of months established (GAP_AGE), total assets (GAP_ASSET), EBITDA to sales ratio (GAP_EBITDAR), and debt ratio (GAP_DEBTR) between the IPO firm and competitors were used. The level of competition in the industry (HHI) is also an important factor, and it has been reported that the entry of newly public companies through large IPOs poses a threat to existing companies in a highly competitive industry (Akhigbe et al. 2003). The Herfindal-Hirschman index (HHI) in this paper is calculated as the sum of the square of the market share based on the annual sales of companies in the industry. The HHI has a value between 0 and 1 , and the closer to 0 , the more intense competition within the industry, and the closer to 1, the higher the industry concentration.

\subsection{Research Method}

This paper uses the traditional event study method to separate the spillover effect of information on competitors from the effect of market entry of new securities on the demand of existing securities. First, using the market model as in Equation (1), the abnormal return before and after the filing date of a registration statement and the listing date is obtained as follows.

$$
A R_{i, t}=R_{i, t}-\alpha_{i}-\beta_{i} R_{m, t}
$$

The market return $(R m, t)$ used in the market model is the daily return of the MKF500 index, which consists of the top 500 large-cap stocks of the KRX, and the market model's beta coefficient is estimated over the period from 20 business days before the filing date of a registration statement to 140 business days before the filing date. Subsequently, the average abnormal return (AAR), which averages the abnormal returns of individual competitors during the event window, is obtained as shown in Equation (2).

$$
A A R_{t}=\frac{1}{N} \sum_{i=1}^{N} A R_{i, t}
$$

Subsequently, the cumulative average abnormal return (CAAR) over the event window starting from the date $\tau 1$ to the date $\tau 2$ is calculated as shown in Equation (3)

$$
\operatorname{CAAR}(\tau 1, \tau 2)=\sum_{\tau=\tau 1}^{\tau 2} A A R_{\tau}
$$

On the other hand, as in the case of this study, a cross-sectional correlation between individual stock returns reduces the standard deviation of AAR when the stock price change of multiple companies is measured on the date of occurrence of one event (for example, the listing date). This leads to an overestimation of the significance of AAR and CAAR (Strong 1992). To prevent this, prior studies have used portfolios of related companies for each event date and then used portfolio returns to measure AAR and CAAR (Lang et al. 1992; Szewczyk, 1992). Therefore, both equally weighted portfolio returns and market-value weighted portfolio returns of the competing firms are calculated and used for data in the event study.

\section{Results}

\subsection{Descriptive Statistics and Univariate Tests}

Table 2. The descriptive statistics of proxy variables for IPO demand shock to the competing firms

\begin{tabular}{llllll}
\hline Variables & Mean & Median & Maximum & Minimum & Standard dev. \\
\hline PROCEED (Bil. Korean won) & 57.6 & 17.1 & 2661.7 & 1.4 & 190.3 \\
FLOAT (\%) & 41.8 & 40.8 & 95.0 & 10.0 & 14.7 \\
DISCOUNT (\%) & 31.1 & 17.3 & 160.0 & -30.0 & 45.5 \\
INDCOMP & 451.0 & 367.0 & 2344.2 & 0.2 & 421.3 \\
INSTCOMP & 160.3 & 78.3 & 887.0 & 0.5 & 189.9 \\
STKBID (\%) & 16.7 & 5.6 & 95.2 & 0.0 & 22.3 \\
\hline
\end{tabular}

Table 2 provides the basic statistics on variables that are expected to affect the demand for stocks of existing competitors in the industry due to the IPO. The average amount of public offering (PROCEED) was 57.6 billion Korean won, which was $9.0 \%$ of the average market capitalization of 639.6 billion Korean won of the existing competitors at the time of IPO, but the deviation of proceeds between IPOs was relatively large. The ratio of the number of shares available for trading (FLOAT), excluding the number of locked-up stocks of large shareholders and ESOP, compared to the number of listed shares represents the size of the potential supply of IPO shares within one 
year after the listing date and reached $42 \%$. On the first day of listing, the closing price of the first day of listing went up to $31 \%$ on average relative to the offer price, which marked a substantial undervaluation of the offer price over the past 11 years. Individual investors' subscription competition (INDCOMP) and the competition rate of institutional investors participating in the book-building process (INSTCOMP) reached 451 to 1 and 160 to 1 on average, respectively, showing strong demand for IPO stocks. During the book-building process, the institutional investor's strike bids ratio (STKBID) reached an average of $17 \%$.

Table 3. The mean [median] of the proxy variables for the industrial competitiveness and test results for their equality

\begin{tabular}{|c|c|c|c|c|}
\hline Variable & & $\begin{array}{l}\text { IPO firms' Mean } \\
\text { [Median] }\end{array}$ & $\begin{array}{l}\text { The Competing Firms' } \\
\text { Mean [Median] }\end{array}$ & $\begin{array}{l}\text { Significance of the Test for } \\
\text { Equality }\end{array}$ \\
\hline AGE (months) & & $173[138]$ & 273 [215] & $* * *[* * *]$ \\
\hline $\begin{array}{l}\text { ASSET (Bil. } \\
\text { Won) }\end{array}$ & Korean & $229.6[68.3]$ & 540.4 [155.9] & $* * *[* * *]$ \\
\hline EBITDAR (\%) & & $11.5[15.4]$ & $13.7[11.8]$ & $*[* * *]$ \\
\hline DEBTR (\%) & & $53.1[38.0]$ & $78.9[52.8]$ & $* * *[* * *]$ \\
\hline $\mathrm{R} \& \mathrm{D}(\%)$ & & 8.7 [2.1] & $2.9[0.9]$ & $* * *[* * *]$ \\
\hline $\mathrm{N}$ & & 531 & 2,443 & \\
\hline
\end{tabular}

Table 3 compares the age and financial ratios of IPO companies and competitors. All figures in Table 3 are based on the end of the year in which the IPO occurred. Compared to the existing publicly traded companies, IPO companies had a shorter corporate history and were relatively smaller in terms of assets compared to their rival firms, and the differences were very significant. However, in terms of operating profitability (EBITDAR), the median value of the IPO firm was about 3.6\% higher than that of the existing listed companies, and the IPO firms' financial structure (DEBTR) was also better than the existing competitors. R\&D expenditure relative to sales (R\&D), which represents the size of expenditure on knowledge capital, is higher than that of IPO companies. That is, IPO companies are making more active investments on the valuable intangible assets than existing companies to secure competitiveness in the industry.

\subsection{Event Studies}

Table 4. The AAR and CAAR of the competing firms around the IPO announcement date $(t=0)(N=531)$

\begin{tabular}{lll}
\hline $\begin{array}{l}\text { Average Abnormal Return } \\
\text { (AAR) }\end{array}$ & $\begin{array}{l}\text { Equally Weighted Portfolio } \\
\text { (EWP) of the Competing Firms }\end{array}$ & $\begin{array}{l}\text { Value-Weighted Portfolio } \\
\text { (VWP) of the Competing Firms }\end{array}$ \\
\hline AAR(-1) & $-0.0005(-0.52)$ & $-0.0004(-0.45)$ \\
AAR $(0)$ & $-0.0000(-0.03)$ & $0.0002(0.15)$ \\
AAR $(+1)$ & $-0.0004(-0.42)$ & $-0.0010(-0.99)$ \\
CAAR $(-1,+1)$ & $-0.0009(-0.50)$ & $-0.0013(-0.70)$ \\
\hline
\end{tabular}

T statistics in parentheses and $*, * *, * *$ denote significance at $10 \%, 5 \%, 1 \%$ respectively.

Table 4 records the change in the competing firms' returns between three days surrounding the filing date $(\mathrm{t}=0)$ of a registration statement to investigate the effect of the IPO's announcement on the stock prices of existing listed companies. Table 4 shows the AAR trend of the value-weighted portfolio as well as the equally weighted portfolio composed of existing competing stocks. In the results of both portfolios, AARs and CAAR $(-1,+1)$ for 3 days before and after the filing of the IPO registration statement, did not show any significant difference from 0 , which means that the public announcement of the IPO does not have any significant effect on the stock price of existing listed companies. This result suggests that IPO information in the stock market is not effectively reflected in the stock price 
of competing companies, or that the IPO announcement is not worth the information that will lead investors to a significant share price response of the competing firms. In either case, the information effect of the IPO disclosure as proposed by Hypothesis 1 is dismissed.

Table 5. The AAR and CAAR of the competing firms around the IPO listing date $(\mathrm{t}=0)(\mathrm{N}=531)$

\begin{tabular}{llll}
\hline $\begin{array}{l}\text { Average Abnormal Return } \\
\text { (AAR) }\end{array}$ & IPO Companies' & $\begin{array}{l}\text { Equally Weighted } \\
\text { Portfolio (EWP) } \\
\text { of the Competing Firms }\end{array}$ & $\begin{array}{l}\text { Value Weighted Portfolio } \\
\text { (VWP) of the Competing } \\
\text { Firms }\end{array}$ \\
\hline CAAR $(-5,-1)$ & - & $-0.0060(-3.21)^{* * *}$ & $-0.0076(-3.81)^{* * *}$ \\
AAR $(0)$ & $0.3110(15.76)^{* * *}$ & $-0.0018(-1.85)^{*}$ & $-0.0017(-1.67)^{*}$ \\
CAAR $(0,+5)$ & $0.2804(12.51)^{* * *}$ & $-0.0059(-2.51)^{* *}$ & $-0.0073(-3.28)^{* * *}$ \\
CAAR $(-5,+5)$ & - & $-0.0119(-3.88)^{* * *}$ & $-0.0153(-4.72)^{* * *}$ \\
\hline
\end{tabular}

T statistics in parentheses and $*, * *, * * *$ denote significance at $10 \%, 5 \%, 1 \%$ respectively.

Table 5 shows the AARs and CAARs of the equally weighted portfolio and value-weighted portfolio composed of the existing listed stocks for 11 days before and after the listing date $(\mathrm{t}=0)$. Also, it shows the comparison of AAR of IPO stocks on the listing date and $\operatorname{CAAR}(0,+5)$ for 6 days after listing. The AAR of an IPO stock is the market-adjusted return, which is the stock return minus the market return (MKF500 index return). Since this study aims to separate the information effect provided by the IPO ahead of listing and the impact of the demand shock on competitors' stocks caused by the actual trading of IPO stock trading, the CAAR(-5,-1) of competing companies before listing and the CAAR $(0,+5)$ after listing were examined separately. Due to the undervaluation of the offer price, the AAR $(0)$ of IPO stocks on the day of listing reached $31 \%$ as expected, but on the other hand, the share price declined by an average of about $3 \%$ over the next five days due to the investor's caution over the excessive rise in the stock price. In the case of competing stocks, statistically significant negative returns were observed in all event windows of $\operatorname{AAR}(0)$ on the day of listing and $\operatorname{CAAR}(-5,-1)$ for 5 days before listing, and $\operatorname{CAAR}(0,+5)$ for 6 days after listing. This fact is different from the fact that in the previous Table 5, where there was no change in the price of the existing listed stocks on the date of the IPO announcement. The risk-adjusted price of the equally (value) weighted portfolio of competitors fell by about $0.6 \%(0.8 \%)$ over the past five days before IPO listing, and even on the day of IPO listing, the prices of existing listed stocks showed a small but statistically significant decline of about $0.2 \%$. During the 6 days after listing, the equally (value) weighted portfolio value of the existing competing stocks additionally fell $0.6 \%(0.7 \%)$ compared to the market, indicating that for 11 days around the listing of IPO stocks, the average share price of existing listed companies fell by about from $1.2 \%$ to $1.5 \%$ compared to the market. This fact suggests that the IPO's information transfer effect will occur on the stock price of competitors ahead of IPO stock listing, while no significant information spillover effect was observed in the IPO announcement. Also, the impact of IPO stocks on the demand for existing stocks was found to be economically significant. Therefore, Hypothesis 2, which presumed a significant decline in the share price of a competitor on IPO's listing day, could not be rejected.

\subsection{Regression Analyses}

Table 6. The results of regression analyses between the IPO Related Variables and the CAAR of the competing firms around the IPO listing date

\begin{tabular}{lllll}
\hline \multicolumn{1}{r}{ Dep.Var. } & Model (i) & Model (ii) & Model (iii) & Model (iv) \\
Indep. Var. & CAAR $(-5,-1)$ & $\operatorname{CAAR}(0,+5)$ & CAAR $(-5,-1)$ & CAAR $(0,+5)$ \\
\hline constant & $-0.026(-0.57)$ & $0.065(0.85)$ & $-0.004(-0.09)$ & $0.015(0.23)$ \\
PINDURET & $0.016(1.95)^{*}$ & $-0.001(-0.08)$ & $0.014(1.71)^{*}$ & $-0.001(-0.12)$ \\
YRDIS & $-0.038(-2.89)^{* * *}$ & $0.001(0.05)$ & $-0.039(-2.94)^{* * *}$ & $0.002(0.08)$ \\
PROCEED & $-0.005(-1.26)$ & $-0.001(-0.10)$ & $0.001(0.38)$ & $-0.002(-0.60)$ \\
FLOAT & $-0.003(-0.26)$ & $0.017(0.98)$ & $-0.002(-0.18)$ & $0.019(1.17)$ \\
\hline
\end{tabular}




\begin{tabular}{|c|c|c|c|c|}
\hline DISCOUNT & $0.007(1.37)$ & $0.000(0.06)$ & $0.009(1.76)^{*}$ & $-0.001(-0.17)$ \\
\hline INDCOMP & $0.003(2.39)^{* *}$ & $0.003(1.69)^{*}$ & $0.003(2.42)^{* *}$ & $0.003(1.68)^{*}$ \\
\hline INSTCOMP & $-0.004(-2.41)^{* *}$ & $-0.002(-0.93)$ & $-0.005(-2.90) * * *$ & $-0.002(-0.98)$ \\
\hline STKBID & $-0.029(-3.34)^{* * *}$ & $-0.035(-2.63)^{* * *}$ & $-0.029(-3.27) * * *$ & $-0.033(-2.45)^{* *}$ \\
\hline IPO_AGE & $-0.005(-1.48)$ & $-0.003(-0.87)$ & & \\
\hline IPO_ASSET & $0.007(1.59)$ & $-0.002(-0.27)$ & & \\
\hline IPO_EBITDAR & $-0.004(-0.90)$ & $-0.010(-2.03)^{* *}$ & & \\
\hline IPO_DEBTR & $0.006(0.81)$ & $0.001(0.14)$ & & \\
\hline IPO_R\&D & $-0.003(-0.46)$ & $-0.024(-3.66)^{* * *}$ & & \\
\hline HHI & $-0.002(-0.08)$ & $0.031(0.84)$ & $0.008(0.26)$ & $0.030(0.80)$ \\
\hline GAP_AGE & & & $0.000(0.20)$ & $0.006(2.94)^{* * *}$ \\
\hline GAP_ASSET & & & $-0.001(-0.65)$ & $0.004(2.03)^{* *}$ \\
\hline GAP_EBITDAR & & & $0.005(0.95)$ & $0.010(2.45)^{* *}$ \\
\hline GAP_DEBTR & & & $-0.003(-1.03)$ & $0.003(1.03)$ \\
\hline GAP_R\&D & & & $0.006(0.84)$ & $0.026(4.48)^{* * *}$ \\
\hline $\mathrm{R}^{2}$ & 0.093 & 0.042 & 0.078 & 0.056 \\
\hline $\mathrm{N}$ & 531 & 531 & 531 & 531 \\
\hline
\end{tabular}

Heteroscedasticity-autocorrelation consistent $\mathrm{t}$ statistics in parentheses and $*, * *, * * *$ denote significance at $10 \%$, $5 \%, 1 \%$ respectively.

Table 6 shows the results of examining the relationship between the IPO variables related to the demand shock and industrial competitiveness and the competitors' returns through regression analysis. Variables such as PROCEED, INDCOMP, INSTCOMP, AGE, and ASSET are transformed into natural logarithmic values in the regression analysis. To examine the information spillover effect and the impact of demand shock of IPO stocks separately, separate regression analyses were performed with $\operatorname{CAAR}(-5,-1)$ of an equally weighted portfolio composed of the competing stocks before listing and $\operatorname{CAAR}(0,+5)$ after listing as dependent variables. In the regression analysis in Table 6, the standard errors of the regression coefficients are corrected for heteroscedasticity and autocorrelation using Newey and West (1987) method. In the regression model ( $i$ ), the CAAR $(-5,-1)$ of competing stocks before the trading of IPO stocks was found to be highly dependent on the past industry return (PINDURET) and the condition of the IPO market (YRDIS) for the past year. In other words, when the industry return rose in the past, the stock prices of competitors also rose ahead of the IPO, whereas if the IPO market has been overheated, it has a negative effect on the price of the existing listed stock, signaling adverse impact on the demand of the competitor's stock. As expected, the higher the institutional investors' demand for IPO stocks (INSTCOMP) and their aggressiveness to buy (STKBID), the more negatively it affects the stock prices of competitors, resulting in a lower CAAR(-5, -1). On the other hand, the higher the individual investor's enthusiasm for subscription to IPO stocks (INDCOMP), the more positively it affects the stock prices of competing companies before listing. In general, institutional investors are recognized as informed traders, and the entry of IPO stocks that institutional investors prefer into the stock market is expected to reduce the investment demand of existing stocks. In contrast, individuals are considered sentimental investors who tend to overreact to market conditions. In particular, in the IPO market, it was found that the investment behavior due to the over-confidence of individual investors caused the IPO stock price to deviate from its fundamental value after listing, and to provoke an immediate price reversal. In this regard, Derrien (2005) argued that when individual investors were optimistic about the stock market, their subscriptions to IPO stocks increased, but the increase of individual investors' subscriptions resulted in a bubble of IPO stocks and a subsequent drop in stock price after listing. Dorn (2009) also cited individual investors' over-subscription of IPO stocks as the cause of high returns on the day of listing and long-term, poor return performance compared to the market or industry in subsequent periods. These results weakly support Hypothesis 3 that strong demand for IPO stocks will lower the stock prices of competing companies. On the other hand, the variables such as PROCEED and FLOAT, related to the size of the supply of IPO stocks, and the financial variables such as age, asset, EBITDA to sales ratio, debt ratio, and R\&D to sales ratio, related to the industrial competitiveness of IPO companies were found not to affect the price of existing stocks before listing. In the regression model (ii) in Table 6, the impact on the demand of existing listed stocks was examined after the trading of IPO stocks began. Contrary to expectations, it was 
observed that the size of proceeds from IPO (PROCEED), which directly represents the volume of the supply of IPO stocks after listing, and the FLOAT ratio compared to listed stocks, do not affect the stock price of competitors. Therefore, Hypothesis 4, which predicted a decline in the share price of existing listed stocks due to the supply of IPO stocks, could not be supported. Among the variables reflecting demand for IPO stocks, the STKBID variable reflecting the strong demand of institutional investors still had a significantly negative impact on the stock prices of competitors even after the IPO stocks began trading. The more popular IPO stocks are to institutional investors, the more negatively it affects the share price of existing competitors. On the contrary, the demand for individual investors' IPO stocks (INDICOMP) also continues to have a positive effect on the share price of competing companies. In the stock market, it seems that IPO stocks with high demand from individual investors will fall immediately after listing, and as a result, it will have a positive effect on the stock prices of competitors. On the other hand, unlike before listing, it was observed that a profitability variable (IPO_EBITDAR) and R\&D intensity (IPO_R\&D) related to the industrial competitiveness of IPO stocks started to have a negative impact on the stock price of existing competitors along with IPO stock trading. Hence, Hypothesis 5, in which the entry into the stock market of a new public company with enhanced competitiveness due to high R\&D investment negatively affects the share price of the existing company, could not be rejected.

To test the robustness associated with the relationship between IPO variables and a competitor's stock price, this study conducted a regression analysis once again using the difference between the financial ratios of competitors and IPO firms as an independent variable of regression analysis instead of the financial ratios of IPO companies. The regression models (iii) and (iv) show the results. The results of the regression models (iii) and (iv) were very similar to those of the regression equations (i) and (ii). Particularly noteworthy is the regression model (iv). The longer a competitor's corporate history (GAP_AGE) is compared to a newly listed company, and the larger the competitor's asset size (GAP_ASSET) is compared to a newly listed company, the more it has a positive impact on the competitor's share price after the listing of IPO stocks. In addition, the higher the profitability (GAP_EBITDAR) of the existing competitors compared to the IPO companies, and the more the existing competitors invested in R\&D (GAP_R\&D) compared to the IPO companies, the higher the share price of the competitors after the listing of IPO stocks. Overall, the results in Table (6) show that the emergence of newly listed companies with strong competitiveness due to high profitability and high $R \& D$ investment has caused the demand of investors, especially institutional investors, negatively affecting the stock prices of existing listed companies. On the other hand, the existing listed competitors with a long history, bigger size, better operating performance, and a lot of R\&D investment can minimize a negative impact on the share price despite IPO companies entering the stock market.

\section{Conclusion}

This study examined the effect of IPO announcement and listing on the stock price of newly listed companies' competitors in the industry in the Korean stock market for 11 years from 2007 to 2017. To investigate the information transfer effect of the IPO and the impact of a demand shock on the stock price of competitors due to the emergence of substitutes for existing listed stocks, this study observed changes in the stock prices of competing companies on the filing date of a registration statement and new listing date, respectively.

Along with the IPO disclosure, the share price of the competitor's equally weighted (value-weighted) portfolio showed no significant change. This suggests that the spillover effect of information, such as the prospect of industries, or changes in the competitiveness of companies within the industry, is not sufficiently reflected in the share price of the competitor on the IPO announcement date. On the other hand, the value of an equally weighted (value-weighted) portfolio for 11 days surrounding the IPO's new listing date fell about 1.2\% (1.5\%) compared to the market.

Along with the listing of IPO stocks, both the demand shock effect and the information spillover effect appear to work in combination with the observed weakness of the competitor's stock price. In terms of the information spillover effect, the institutional investors' strong demand for IPO stocks has led to a weak share price of competing companies along with the listing. This suggests that as the IPO related information was revealed through the public offering process such as book-building, it negatively affected the stock demand as well as the share prices of competing companies. Unlike institutional investors, individual investors' demand for IPO stocks did not lead to reduced demand for competitors' stocks. Rather, the increase in the demand for IPO stocks by individual investors resulted in the rise in the share price of competing companies. It can be interpreted that the oversubscription of individual investors caused a high valuation of IPO stocks followed by an immediate price reversal, which would have a positive impact on the stock price of existing competitors. It was also observed that the variables representing the size of the IPO-induced supply shock, such as the public offering amount of IPO stocks or the number of stocks 
that can be traded immediately after listing relative to the number of listed stocks, do not affect the stock price of a competitor. Therefore, it was not possible to prove that the drop in the stock price of a competing company due to the IPO stock listing was due to a drop in demand for existing stocks due to an increase in the supply of new public offerings.

On the other hand, it has been observed that factors related to relative competitiveness in the industry, such as IPO company's operating profitability, and investment in knowledge capital, are related to the decline in the stock price of existing listed companies. In particular, the competitive effect overwhelms the contagion effect in terms of the information spillover effect, in that the share price of the competitor fell along with the IPO listing.

\section{Acknowledgment}

The author gratefully acknowledges the financial support of Seowon University in conducting the research.

\section{References}

Akhigbe, A., Borde, S. F., \& Whyte, A. M. (2003). Does an Industry Effect Exist for Initial Public Offerings? Financial Review 38(4), 531-551. https://doi.org/10.1111/1540-6288.00059

Baker, M., \& Wurgler, J. (2000). The Equity Share in New Issues and Aggregate Stock Returns. Journal of Finance 55(5), 2219-2257. https://doi.org/10.1111/0022-1082.00285

Bradley, D., \& Yuan, X. (2013). Information Spillovers around Seasoned Equity Offerings. Journal of Corporate Finance, 21(1), 106-118. https://doi.org/10.1016/j.jcorpfin.2013.01.006

Braun, M., \& Larrain, B. (2009). Do IPOs Affect the Prices of Other Stocks? Evidence from Emerging Markets. Review of Financial Studies, 22(4), 1505-1544. https://doi.org/10.1093/rfs/hhn025

Chan, S. H., Martin, J. D., \& Kensinger, J. D. (1990). Corporate Research and Development Expenditures and Share Value. Journal of Financial Economics 26(2), 255-276. https://doi.org/10.1016/0304-405X(90)90005-K

Chemmanur, T.J. \& He, J. (2011). IPO Waves, Product Market Competition, and the Going Public Decision: Theory and Evidence. Journal of Financial Economics 101(2), 382-412. https://doi.org/10.1016/j.jfineco.2011.03.009

Chen, S. S., Ho, L. C., \& Shih, Y. C. (2007). Intra-Industry Effects of Corporate Capital Investment Announcements. Financial Management, 36(2), 1-21. https://doi.org/10.1016/j.jfineco.2011.03.009

Chod, J., \& Lyandres, E. (2011). Strategic IPOs and Product Market Competition. Journal of Financial Economics 100(1), 45-67. https://doi.org/10.1016/j.jfineco.2010.10.010

Derrien, F. (2005). IPO Pricing in Hot Market Conditions: Who Leaves Money on the Table?. Journal of Finance 60(1), 487-521. https://doi.org/10.1111/j.1540-6261.2005.00736.x

Dorn, D. (2009). Does Sentiment Drive the Retail Demand for IPOs?. Journal of Financial and Quantitative Analysis 44(1), 85-108. https://doi.org/10.1017/S0022109009090024

Foster, G. (1981). Intra-Industry Information Transfers Associated with Earnings Releases. Journal of Accounting and Economics, 3(3), 201-232. https://doi.org/10.1016/0165-4101(81)90003-3

Hsu, H. C., Reed, A. V., \& Rocholl, J. (2010). The New Game in Town: Competitive Effects of IPOs. Journal of Finance, 65(2), 495-528. https://doi.org/10.1111/j.1540-6261.2009.01542.x

Lang, L. H. P., \& Stulz, R. M. (1992). Contagion and Competitive Intra-industry Effects of Bankruptcy Announcements. Journal of Financial Economics, $32(1), \quad$ 45-60. https://doi.org/10.1016/0304-405X(92)90024-R

Laux, P., Starks, L. T., \& Yoon, P. S. (1998). The Relative Importance of Competition and Contagion in Intra-Industry Information Transfers: An Investigation of Dividend Announcements. Financial Management, 27(3), 5-16. https://doi.org/10.2307/3666270

Li, Y., Shen, D., Wang, P., \& Zhang, W. (2019). Do Analyst Recommendations Matter for Rival Companies?. International Review of Financial Analysis, 65, 1-18. https://doi.org/10.1016/j.irfa.2019.101380

Li, Y., Sun, Q., \& Tian, S. (2018). The Impact of IPO Approval on the Price of Existing Stocks: Evidence from China. Journal of Corporate Finance, 50, 109-127. https://doi.org/10.1016/j.jcorpfin.2018.03.002

Lowry, M., \& Schwert, G. W. (2002). IPO Market Cycles: Bubbles or Sequential Learning?. Journal of Finance, 57(1), 1171-1200. https://doi.org/10.1111/1540-6261.00458 
McGilvery, A., Faff, R., \& Pathan, S. (2012). Competitive Valuation Effects of Australian IPOs. International Review of Financial Analysis, 24, 74-83. https://doi.org/10.1016/j.irfa.2012.08.002

Myers, S. C., \& Majluf, N. S. (1984). Corporate Financing and Investment Decisions When Firms Have Information that Investors Do Not Have. Journal of Financial Economics, 13(2), 187-221. https://doi.org/10.1016/0304-405X(84)90023-0

Newey, W. K., \& West, K. D. (1987). A simple positive Semi-definite Heteroskedasticity and Autocorrelation Consistent Covariance Matrix. Econometrica, 55(3), 703-708. https://doi.org/10.2307/1913610

Norman, S. (1992). Modeling Abnormal Return: A Review Article. Journal of Business Finance and Accounting, 19(4), 533-553. https://doi.org/10.1111/j.1468-5957.1992.tb00643.x

Ritter, J. R. (1991). The Long-Run Performance of Initial Public Offerings. Journal of Finance, 46(1), 3-27. https://doi.org/10.1111/j.1540-6261.1991.tb03743.x

Slovin, M. B., Sushka, M. E., \& Bendeck, Y. M. (1991). The Intra-Industry Effects of Going-Private Transactions. Journal of Finance, 46(4), 1537-1550. https://doi.org/10.1111/j.1540-6261.1991.tb04630.x

Slovin, M. B., Sushka, M. E., \& Ferraro, S. R. (1995). A Comparison of the Information Conveyed by Equity Carve-Outs, Spin-Offs, Asset Sell-Offs. Journal of Financial Economics, 37(1), 89-104. https://doi.org/10.1016/0304-405X(94)00796-4

Szewczyk, S. H. (1992). The Intra-Industry Transfer of Information Inferred from Announcements of Corporate Security Offerings. Journal of Finance, 47(5), 1935-1945. https://doi.org/10.1111/j.1540-6261.1992.tb04689.x

\section{Copyrights}

Copyright for this article is retained by the author(s), with first publication rights granted to the journal.

This is an open-access article distributed under the terms and conditions of the Creative Commons Attribution license (http://creativecommons.org/licenses/by/4.0/). 